Anna Majewska-Tworek • (1)

Uniwersytet Wroclawski, Wroclaw

anna.majewska-tworek@uwr.edu.pl

Monika Zaśko-Zielińnka •

Uniwersytet Wrocławski, Wrocław

monika.zasko-zielinska@uwr.edu.pl

\title{
FUNKCJE WYRAZÓW O POSTACI JAKBY W NIEOFICJALNYCH I OFICJALNYCH WYPOWIEDZIACH MÓWIONYCH. NA PODSTAWIE BADAŃ KORPUSOWYCH ${ }^{1}$
}

Słowa klucze: tekst mówiony, wypowiedź nieoficjalna, wypowiedź oficjalna, części mowy, słowniki Keywords: oral text, unofficial utterance, official utterance, parts of speech, dictionaries

\section{Wstęp}

Podjęcie szczegółowej analizy wyrazów o wysokiej frekwencji w mówionej odmianie polszczyzny ${ }^{2}$ wiąże się ze spostrzeżeniami poczynionymi w badaniach nad niepłynnością wypowiedzi (Majewska-Tworek 2014). Wówczas w oficjalnych wypowiedziach stwierdzono m.in. bardzo wyraźne występowanie wyrazów retardacyjnych, czyli takich, które zwalniają tempo mówienia, ułatwiając jego kontynuowanie. Wspólne dla wypowiedzi badanych mówców okazały się wyrazy no, właśnie i jakby. Inne były raczej charakterystyczne dla poszczególnych osób (kilku lub nawet tylko jednej). Wyraz jakby jest typowy przede wszystkim dla mówionej odmiany języka

1 Wkład każdej z autorek jest równy i wynosi po $50 \%$.

2 Artykuł jest częścią większego projektu: Operatory metatekstowe w oficjalnym i nieoficjalnym tekście mówionym. Analiza na materiale korpusowym. Dotychczas ukazały się prace: Majewska-Tworek, Zaśko-Zielińska 2016, 2018. 
polskiego. Jest często używany, a w opinii językoznawców normatywnych - wręcz nadużywany.

Wykres 1. Profil występowania jakby w NKJP

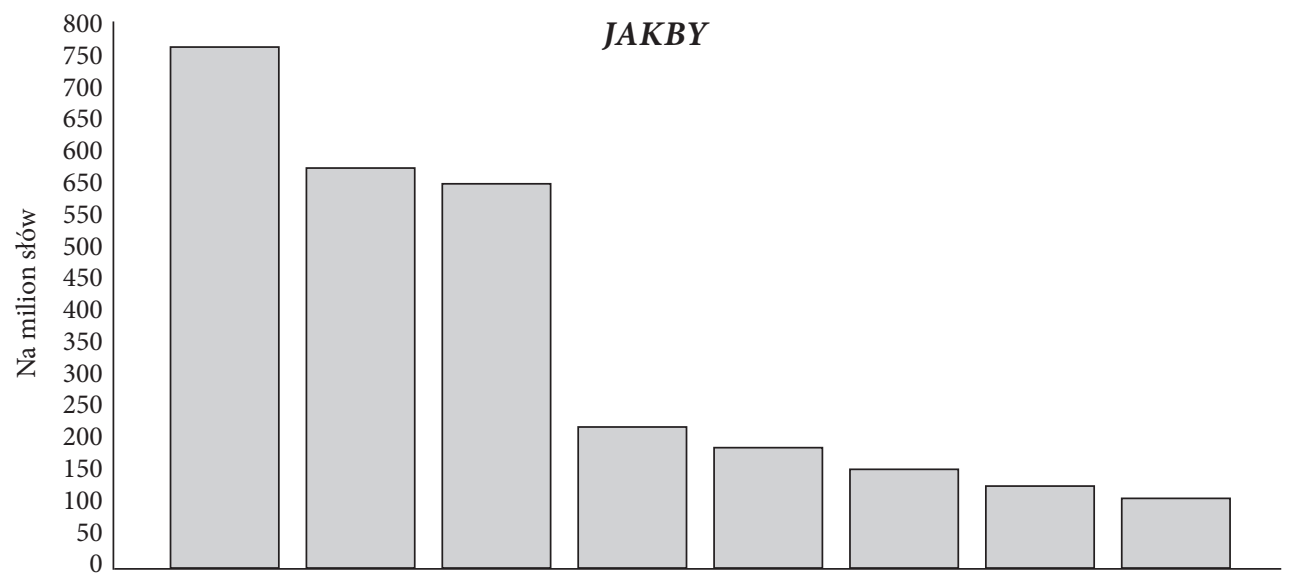

Kanały (od lewej): mówiony, rękopis, książka, prasa - miesięcznik, prasa - inne, Internet, prasa - tygodnik, prasa - dziennik

Badania $\mathrm{w}$ nurcie pragmalingwistyki oraz psycholingwistyki wykazują, że istnieją jednak określone przyczyny używania wyrazów typu jakby (właśnie, no, znaczy itp.) przez mówców realizujących swoją spontaniczną wypowiedź w sytuacjach nieoficjalnych i oficjalnych (Milczanowska-Matejczyk 2009). Warto zaznaczyć, że studia nad pracami poświęconymi funkcji jakby w wypowiedziach mówionych (Żabowska 2007; Milczanowska-Matejczyk 2009; Majewska-Tworek 2014) wykazują charakterystyczną cechę: w zgromadzonym przez badaczki materiale znalazły się wyłącznie partykuły.

\section{Jakby - części mowy}

Istniejące opisy leksykograficzne wyrazów o postaci jakby klasyfikują je w ramach dwóch różnych części mowy: partykuł i spójników. Najbardziej szczegółowe informacje na temat typu partykuły uwzględnia WSJP PAN, w którym dookreślono ją jako: partykułę epistemiczna niepotwierdzająca (por. Żabowska 2006: 207-208).

Mimo że w Słowniku gniazdowym partykuł polskich (SGPP) wyróżniona została grupa partykuł epistemicznych, to jakby umieszczone jest w grupie partykuł komentujących mówienie i jest przykładem partykuły namysłu. Cechą wspólną wymienionych jednostek jest „komentowanie wyboru tego, co nadawca mówi w remacie wy- 
powiedzenia [...]", gdyż mówiący nie jest przekonany co do tego wyboru (ibid.: 35). Stąd partykuła jakby definiowana jest w słownikach ogólnych jako: 'komunikująca, że wyrażony w zdaniu sąd nie odpowiada dosłownie faktycznemu stanowi rzeczy, ale jest mu w znacznym stopniu bliski' (USJP); 'poprzedzająca składnik zdania, który wprawdzie nie odpowiada rzeczywistości, ale w znacznym stopniu ją przypomina' (ISJP); 'wyrażająca niepewność mówiącego wobec dosłownie rozumianej treści wyrazu, z którym współwystępuje' (PSWP). Wszystkie przytoczone definicje wskazują dwie cechy partykuły jakby: to, że nie odnosi się do rzeczywistości, ale raczej do sytuacji tworzenia wypowiedzi, w której nadawca próbuje dobrać odpowiednie słowa, ale ma świadomość ich niedoskonałości.

Jakby klasyfikowane jako spójnik opisywane jest w analizowanych słownikach w dwóch odrębnych znaczeniach. Pierwsze z nich odwołuje się do spójnika podrzędnego charakteryzowanego przez znaczenie: 'określające sytuację nierzeczywistą, która, biorąc pod uwagę to, o czym mowa w zdaniu nadrzędnym, mogłaby się urzeczywistnić (USJP) lub funkcję: 'łączy porównywane fragmenty tekstu' (SWJP). W ISJP frazę typu JAKBY opisano we Wstępie do słownika w ramach podrozdziału Inne oznaczenia gramatyczne: 'fraza typu JAKBY - oznaczenie stosowane w schematach składniowych jednostek, które łączą się ze zdaniem podrzędnym porównawczym wprowadzanym spójnikiem jakby lub jak gdyby' (ISJP I: XLI). Ponadto w części zasadniczej słownika spójnik ten opisany został jako centralny aglutynacyjny $^{3}$, który w zdaniu nadrzędnym może być poprzedzony przez tak, synonimiczne: tak jakby (ISJP). W WSJP PAN analogiczne jakby zaklasyfikowano jako włącznik (por. Wajszczuk 1997). Warto zaznaczyć, że spójnika tego nie odnotowano w Słowniku gramatycznym języka polskiego (SGJP). Drugi leksem spójnikowy to jakby (synonimy: gdyby, jeśliby) charakteryzowany jako spójnik podrzędny, warunkowy, przestawny, aglutynacyjny, który 'w prowadza w zdaniu podrzędnym warunek możliwy do spełnienia; zdarzenie, o którym mowa w zdaniu nadrzędnym, może nastąpić w bliższej lub dalszej przyszłości' (USJP). W PSWP oprócz relacji czasowych łączących zdania składowe łączone przez jakby wymienia się też stosunki czasowe.

\section{Intonacja}

W zgromadzonym materiale najwięcej poświadczeń jakby wystąpiło w funkcji partykuły. Maciej Grochowski, odróżniając partykułę od przysłówka, napisał: „partykuła to leksem o zmiennej dystrybucji, zależnej od jego szyku i miejsca akcentu zdaniowego, wchodzący w relację syntaktyczną z dowolnym składnikiem zdania" (Grochowski 1984: 80). Już taka definicja wskazuje na to, że przypisanie partykuły jakby do określonego członu wypowiedzi nie jest zawsze oczywiste i jest możliwe głównie dzięki odsłuchowi odpowiedniego fragmentu nagranej wypowiedzi.

Występuje między łączonymi zdaniami lub członami zdania (ISJP I: XXXVII). 
Zmienny szyk partykuły jakby, jako jej cecha definicyjna (SGPP), wzmaga czujność badacza już w trakcie analizy tych przykładów, w których badany leksem występuje w swej funkcji prymarnej (ibid.), bez towarzyszących dodatkowych wykładników niepewności mówcy. Dość dobrze zagadnienie to ilustruje poniższy przykład. Warto zauważyć, że w bardzo krótkim odcinku czasowym badany wyraz wystąpił dwa razy. Jego pierwsze użycie odnosi się do wyrazu, który nie stoi w jego bezpośrednim sąsiedztwie: „jakby się (.) ten wektor zwrócił”. Natomiast drugie - do wyrazu występującego tuż przed analizowaną partykułą: „zwrócił na zewnątrz jakby”:

także tutaj jakby się (.) ten wektor zwrócił na zewnątrz jakby zjednoczono się $\mathrm{w}$ ramach $($.$) kultury niemieckiej (0,4)$ wobec $(0,4)^{4}$ kultury francuskiej.

Kolejny przykład także ilustruje wyraźne intonacyjne powiązanie jakby z wyrazem, który występuje tuż przed nim. Modyfikowany jest więc wyraz nie daje. Mówca łączy jednym konturem intonacyjnym segment nie daje jakby, a następnie realizuje część rematyczną swojej wypowiedzi. Czyni to z bardzo mocnym zaakcentowaniem pierwszego jej członu (miarodajnego). Analiza prozodii w tego typu miejscach jest ważna m.in. dlatego, że mówca nie zrobił pauzy na granicy tematu i rematu. Ponadto jego wypowiedź ma znaczne tempo, a wdechy, które są oczywiście swoistymi pauzami, nie pełnią tu funkcji segmentującej wypowiedź w sensie semantyczno-gramatycznym.

ankieta przeprowadzona na kilkunastu osobach powiedzmy nie na zwykłych czytelnikach już jest pewnym problemem bo nie daje jakby miarodajnego ${ }^{\circ}{ }^{5}$ obrazu tego wszystkiego ${ }^{\circ}$.

Wyraz jakby pojawia się również w kontekstach bardziej skomplikowanych niż te przytoczone powyżej. W bezpośrednim otoczeniu badanego leksemu mogą bowiem wystąpić różnego typu wykładniki niepewności mówcy. Mogą to być pauzy właściwe (momenty ciszy), pauzy wypełnione (yyy) oraz autokorekty. Analiza intonacji $\mathrm{w}$ takich kontekstach ułatwia m.in. potwierdzenie zmiennego szyku partykuły jakby: w postpozycji (przykład tuż poniżej) czy prepozycji (przykład następny):

- (o,7) yyy współcz (.) yyy współcześnie yyy hhho $(2,6)$ w $(0,5)$ dworku (jakby) $(0,3)$ yyy korczyńskich yyy oh;

- bardziej się liczy struktura niż elementy które tę strukturę tworzą jakby są one w p połączeniu $(0,2)$ wielu wielorakich połączeniach ((niezrozumiałe)).

4 W nawiasach oznaczono długość pauzy w sekundach, symbol (.) oznacza pauzę krótszą niż o,2 sekundy. Natomiast podkreślenie oznacza całość intonacyjną.

5 Symbol oh oznacza wdech (mieszczący się w przedziale czasowym o,2-0,5 s), a hhh ${ }^{\circ}$ - wydech (mieszczący się w przedziale czasowym o,5-0,8 s). Więcej o konwencji transkrypcyjnej por. m.in.: Majewska-Tworek 2014: 21. 
Starannego odsłuchu wymagają również wyrazy jakby w funkcji spójników. Poniższy przykład nie budzi, jak się wydaje, wątpliwości interpretacyjnej. Wyraz jakby występuje tu jako spójnik centralny, aglutynacyjny, odnoszący się do sytuacji nierzeczywistej (por. część niniejszego tekstu o jakby i częściach mowy):

- no tak to pani sformułowała jakby to było $(0,3)$ prawie identyczne.

Struktura powyższego wypowiedzenia jest wręcz wzorcowa dla konstrukcji warunkowej, nierzeczywistej. Analiza intonacji potwierdza to, co sugeruje interpretacja samego transkryptu.

Jednak są też miejsca wątpliwe, przy których łatwo popełnić błąd i pomylić spójnik z zaimkiem przysłownym, aglutynacyjnym.

\section{Analiza przykładów użycia jakby w rozmowach oficjalnych i nieoficjalnych}

Materiał wykorzystany do niniejszej analizy pochodzi z dwóch różnych korpusów: WDK Spokes (rozmowy nieoficjalne) i GeWiss (rozmowy oficjalne - egzaminacyjne). Z każdego korpusu wybrano losowo po 100 przykładów. Analizę materiału z poszczególnych korpusów przeprowadzano oddzielnie, a następnie porównano ze sobą uzyskane wyniki. Wstępny ogląd obu zbiorów potwierdził występowanie jakby zarówno w funkcji partykuły, jak i spójnika. Jednak łatwo zauważono istotną różnicę ilościową w występowaniu jakby jako spójnika czy partykuły w tych dwóch typach rozmów. Pogłębiony przegląd kontekstów z jakby pozwolił na zaproponowanie następującej klasyfikacji funkcji jakby w oficjalnej i nieoficjalnej rozmowie.

1. Partykuła jakby osłabiająca znaczenie i stanowczość stwierdzeń:

a) asekuracja („po stronie nadawcy”): nadawca osłabia odpowiedzialność za użyte słowo;

b) modalność hipotetyczna: coś jest podobne do czegoś; opisywanie nietypowych rzeczy czy zjawisk.

2. Partykuła jakby zdeleksykalizowana lub o osłabionym znaczeniu:

a) uspójniająca - ułatwia rozpoczynanie, kontynuowanie, wygaszanie mówienia; towarzyszy także urwaniom różnego typu;

b) retardacyjna - występuje w sytuacjach szczególnego nagromadzenia innych wykładników niepewności mówcy, towarzyszy też autokorektom.

3. Spójnik jakby.

W przypadku niektórych poświadczeń wyrazu jakby granica między poszczególnymi podtypami jest niewyraźna i trudna do ustalenia. Na podobny problem zwracają uwagę inni badacze polszczyzny mówionej (Danielewiczowa 2006). Jednak 
wszystkie wyrazy jakby poddają się uporządkowaniu na najwyższym poziomie zaproponowanej klasyfikacji.

Chcąc uzyskać klasyfikację rozłączną, kryteria podziału doprecyzowano wskazówkami wynikającymi z samych transkrypcji. Do pierwszej grupy partykuł zostały zaliczone więc te realizacje jakby, którym nie towarzyszyły żadne dodatkowe wykładniki niepewności. Uznano, że wykładniki niepewności mówcy niosą informację o potrzebie zwalniania tempa mówienia; tego typu przykłady zaliczano do grupy partykuł retardacyjnych. Urwanie potraktowano jako nieudaną próbę kontynuowania spójnej wypowiedzi (por. powyżej - pkt 2a) w klasyfikacji), a autokorektę (por. powyżej - pkt 2b) w klasyfikacji) jako symptom wysokiej autokontroli mówcy, który nie tylko zwalnia, ale i cofa swoją wypowiedź, by ją skorygować.

\section{Jakby - rozmowa potoczna}

Analiza 100 przykładów z WDK Spokes pozwoliła wyłonić: 66\% partykuł i 34\% spójników, a także dostrzec bardzo interesujący udział różnych typów partykuł i spójników w rozmowie potocznej oraz ich genologiczne uwarunkowania.

\section{Partykuła}

W rozmowach potocznych najliczniejsza jest partykuła jakby osłabiająca znaczenie i stanowczość znaczenia (36\%) (zob. tabela 1 podsumowująca artykuł), ale szczególnie wyróżniają się $\mathrm{w}$ tej grupie partykuły powiązane z deskryptywnym rozwinięciem tematu, a zwłaszcza sekwencją opisu związaną z porównywaniem (Żydek-Bednarczuk 2005: 138). Mówiący próbuje przedstawić odbiorcy coś, czego on nie widział, co jest nietypowe lub rzadkie. Jakby znaczy tu: 'nie taki sam, trochę podobny do', a osłabienie znaczenia nie jest rodzajem asekuracji mówcy (gdyż w rozmowie potocznej nie czuje się oceniany), ale wynika z inherentnych cech przedstawianych zjawisk (24\%). Nadawca wyraźnie zaznacza zatem, że używane środki językowe mogą jedynie przybliżyć opisywane obiekty lub zjawiska (modalność hipotetyczna):

- przysługuje ci normalnie jakby prawo przenocowania gdziekolwiek w nocy wylądujesz biwak jedno jednonocny;

- zaczęło mu rosnąć taki wielki guz jakby/ nie wiem co to jest bo jest mi ciężko naprawdę opisać.

W teoretycznej analizie zebranych przykładów Magdalena Żabowska zaliczyła jakby do wyrażeń nieimplikujących prawdziwości wygłaszanego sądu. Zauważyła jednocześnie, że prymarnym powodem używania tych jednostek ,jest podstawowa 
zasada związana z mówieniem, mianowicie nakaz mówienia tego, o czym się sądzi, że jest prawdą" (Żabowska 2007: 455). W kontekście takiego opisu jednostkę jakby zaliczyła do partykuł niepotwierdzających. Wydaje się, że w analizowanych rozmowach potocznych partykuła ta służy do kontrolowania budowanej wypowiedzi i budowania porozumienia między nadawcą a odbiorcą, gdyż sygnalizowane osłabienie znaczenia jest nie tylko związane ze sposobem mówienia nadawcy, ale także z przewidywaniem reakcji odbiorcy, którego trzeba dopiero naprowadzić na określony sposób myślenia, podsuwając mu stopniowo pewne przybliżenia obrazów opisywanej rzeczywistości. Na opisaną semantyczną funkcję partykuły nakładają się użycia spójnika centralnego jakby, który również wprowadza relacje podobieństwa. Zresztą w dokumentacji partykuły tak jakby w SGPP podano m.in.: ISJP w haśle „jakby”, spójnik centralny (SGPP: 127).

Druga grupa najczęstszych partykuł w rozmowach potocznych to partykuły o osłabionym znaczeniu i zdeleksykalizowane (30\%), które w rozmowie potocznej pomagają $\mathrm{w}$ tworzeniu spójnego i płynnego tekstu. W analizowanym materiale nie odnajdujemy jednak partykuły jakby na starcie wypowiedzi. Partykuła jakby ułatwia w rozmowie potocznej kontynuowanie mówienia, nie wpływając na osłabianie znaczenia sąsiadujących wyrazów:

- znaczy to jest podstawa po prostu komunikacja teraz jest najważniejszą dziedziną jakby inwestycji na świecie no wiadomo internet komóry;

- bo to by było trzeba zacząć od drugiej strony oczywiście czyli nie od zakładania jakby firmy tylko od znalezienia y klienta pierwszego.

Inny jest kontekst użycia jakby w urwaniach i przerwaniach, w których partykuła ta stanowi miejsce przejęcia tury. Mówiący finalizuje replikę użyciem jakby, które oznacza koniec jego wypowiedzi, a jednocześnie odesłanie do charakterystycznej dla rozmowy potocznej wiedzy wspólnej. Takie działanie mówcy usprawiedliwia możliwość przejęcia tury przez kolejną osobę, gdyż wprowadzenie jakby jest sygnałem finalizowania informacyjnego etapu wypowiedzi, co podkreślane jest często przez ściszenie głosu:

- A: a tam leją wodą po kamieniach i jeszcze witkami takimi brzozowymi cię na napieprzają po po plecach po po klatce piersiowej;

- B: czyli ta para cię jakby;

- A: tak tam w ogóle jak pierwszy raz tam wszedłem to;

- A: przecież to jest nawet gorzej niż te dwa trzy cztery lata zaraz po tym jakby;

-B: no/ no pewno bez porównania.

W grupie partykuł zdeleksykalizowanych i o osłabionym znaczeniu wyróżnia się grupa retardacyjna (9\%), która zarówno służy uspójnianiu wypowiedzi, jak 
i wprowadza osłabioną asekurację. Retardacyjne jakby pojawia się w otoczeniu innych tego typu środków, (np.: no, wiesz, zaimków wskazujących), którym towarzyszą powtórzenia. Daje czas na znalezienie słowa, osłabia stanowczość wypowiedzi, a jednocześnie zapewnia płynność mówienia:

- tylko że to bardziej jakby nie tyle wiesz jakby jej chęci co techniczna strona tego przedsięwzięcia;

- to się jakby taki taki wiesz no/ powiedziałabym że elitarna była ta szkoła;

- tak tak znaczy położne lekarz jest tam jakby na no na takie wiesz pogadanki tam pierdoły i położna normalnie tam to jest generalnie oddychanie torem przeponowym.

\section{Spójnik}

Identyfikacja spójników (czy też jednostek leksykalnych opisywanych w słownikach jako spójniki czy włączniki) w materiale rozmów potocznych sprawia wiele trudności. Tekst mówiony nie jest bowiem wypowiedzią opracowaną, powstaje spontanicznie i rządzi się zupełnie innymi zasadami niż tekst pisany. Przykładowo zdania warunkowe jako wypowiedzenia złożone powinny ustalać relacje przyczynowo-skutkowe między dwoma zdarzeniami (Grzegorczykowa 1996: 135). Natomiast w eliptycznych konstrukcjach mówionych jedno ze zdarzeń bardzo często jest pomijane i pozostaje jedynie w domyśle ze względu na znany rozmówcom kontekst sytuacji lub wiedzę wspólną:

- wiesz co jakbyś spruła dasz radę spruć ten sweter;

- no stary jakbyś się wywalił.

Dwa pierwsze przykłady nie tyle mówią o warunkach zaistnienia jakiegoś zdarzenia, ile powinny być raczej rozumiane mniej dosłownie, jako pewien rodzaj prośby (por.: gdyby pani była tak dobra, żeby to dla mnie zrobić, byłbym bardzo wdzięczny).

Oprócz niepełnych konstrukcji warunkowych w materiale znalazły się także repliki z typowym dla tego typu wypowiedzeń odwołaniem do dwóch zdarzeń:

- no jakby Ania zrobiła to sprawa by była jasna;

- jakbym się skupił to bym sam lepiej wydziergał to.

Łącznie w analizowanym materiale udało się zidentyfikować 26 wystąpień potocznego spójnika warunkowego ${ }^{6}$ jakby z pewnością wymagającego dalszych badań,

6 Według klasyfikacji Jadwigi Wajszczuk są to operatory przywypowiedzeniowe (Wajszczuk 2011: 282). 
gdyż dotąd koncentrowano się głównie na jego synonimach: gdyby, jeśliby, które mogą mieć jednak nieco inny zakres.

W rozmowach potocznych zdecydowanie rzadsze od spójników warunkowych są wystąpienia jakby, które określane są mianem włącznika lub spójnika centralnego ${ }^{7}$. Spójnik ten jest homonimiczny w stosunku do partykuły tak jakby (SGPP: 126) ${ }^{8}$. Jego synonimem jest jak gdyby, a w zdaniu nadrzędnym bardzo często towarzyszy mu zapowiednik tak, który zgodnie z regułami interpunkcji może również znaleźć się w zdaniu podrzędnym i poprzedzać jakby (tak jakby). W materiale rozmów potocznych znajdujemy jednak zarówno przykłady z zapowiednikami w zdaniu nadrzędnym, jak i bez nich:

- i tak pokazali no teraz sobie wyobrażam właśnie spotkanie nasze jakby teraz wyszła;

- tak było słychać jakby gaz z teczki wylatywał.

\section{Wyrazy o postaci jakby w rozmowie egzaminacyjnej}

Jak zostało podane powyżej, z części korpusu GeWiss zawierającej transkrypty rozmów egzaminacyjnych losowo wybrano 100 kontekstów z użyciem badanego wyrazu. Analiza jakby, przeprowadzona zgodnie z przyjętym podziałem funkcji tego wyrazu w wypowiedzi mówionej, przyniosła następujące wyniki:

1) partykuła jakby osłabiająca znaczenie i stanowczość stwierdzeń - 15 przykładów;

2) partykuła jakby z osłabionym znaczeniem leksykalnym lub całkowicie zdeleksykalizowana -83 przykłady:

a) ułatwiająca rozpoczynanie, kontynuowanie, wygaszanie mówienia - 25 przykładów;

b) retardacyjna -58 przykładów;

3) spójnik jakby - 2 przykłady.

Ze względu na wysoki stopień oficjalności rozmowy egzaminacyjnej wśród opisywanych w tym miejscu przykładów trudno z pełną odpowiedzialnością wyróżnić te, które dotyczą modalności hipotetycznej. Pierwszą grupę tworzą raczej wyłącznie przykłady z wyrazami jakby występującymi w funkcji partykuły asekuracyjnej. Stanowi ona 15\% przeanalizowanego materiału. M. Żabowska (2007), charakteryzując ten typ jednostek, zwróciła uwagę, że komunikują one wysoki poziom autokontrolowania wypowiedzi. Sytuacja egzaminacyjna wymaga właśnie takiej wzmożonej

7 Spójnik ten jest odnotowany w słownikach ogólnych, ale nie ma go w SGJP.

8 W SGPP odnajdujemy przykład użycia spójnika tak jakby: A potem zacisnęła mocno pięść, tak jakby jeszcze chciała go choć na trochę zatrzymać! To samo zdanie mogłoby mieć również interpunkcję: A potem zacisnęła mocno pięść tak, jakby jeszcze chciała go choć na trochę zatrzymać! 
autokontroli w trakcie mówienia. Ponadto warto zauważyć, że wyróżniony typ partykuły pojawia się w wypowiedziach obu stron interakcji werbalnej, czyli zarówno u egzaminowanych studentów, jak i u egzaminatorów.

- najogólniej rzecz biorąc instrumentalizm to był oh yyy $(0,3)$ to była taka yyy yyy tendencja yyy w nauce która jakby odbierała wartość samemu realizmowi (student);

- człowiek jest także istotą biologiczną jakby podporządkowaną układom natury (egzaminator).

Użycie partykuły jakby nie jest więc związane z niewiedzą mówiącego. Wyraz jakby jawi się jako jednostka sygnalizująca niepewność mówcy w zakresie „JAK powiedzieć (a nie: CO powiedzieć)”. Oznacza więc jego asekurację w procesie doboru środków językowych (por. opis operatorów nieostrości: Doboszyńska-Markiewicz 2015). Sygnalizuje - jak podkreślono wcześniej - swoiste monitorowanie wypowiedzi. M. Żabowska pisze wprost: „za pomocą analizowanych jednostek stosuje się swego rodzaju monitoring - uprzedza się odbiorcę, że to, co zostanie powiedziane, nie odpowiada rzeczywistości w sposób ścisły [...]" (Żabowska 2007: 458; por. też: eadem 2006: 207).

Jednak w zbiorze przykładów największą część stanowią partykuły o osłabionym znaczeniu leksykalnym lub nawet całkowicie zdeleksykalizowane (83\%), natomiast pełniące funkcję, która w istotny sposób wiąże się z trudem bieżącej realizacji wypowiedzi przez mówcę. Zauważono przy tym, że część z nich wspomaga uspójnianie tekstu mówionego: pojawia się na starcie mówienia, wielokrotnie w trakcie kontynuowania wypowiedzi, może być również sygnałem wygaszania aktywności mówcy (por.: pkt 2a) w klasyfikacji). Tego typu partykuły to $25 \%$ analizowanych przykładów. Warto podkreślić, że stosowanie wyrazu jakby w funkcji ułatwiającej kontynuowanie wypowiedzi jest idiolektalne. W badanym materiale szczególnie wyraźnie charakteryzowało dwóch mówców: KP, czas mówienia: 11 min $48 \mathrm{~s}-31$ powtórzeń jakby; PR, czas mówienia: 3 min $16 \mathrm{~s}-11$ powtórzeń jakby. Część partykuł pełniła właśnie opisywaną funkcję. Wyróżnia je to, że w zdecydowanej większości nie pojawiają się w ich najbliższym otoczeniu nagromadzone w szczególny sposób wykładniki niepłynności mówienia.

- ((mlaszcze)) oczywiście yyy jakby problem artysty w modernizmie yyy ((mlaszcze)) był to jakby jeden $\mathrm{z}$ podstawowych problemów i ${ }^{\circ} \mathrm{h}$ tak jakby w przeciwieństwie postawiony do pozytywizmu oczywiście w pozytywizmie artysta ${ }^{\circ}$ yyy to był ten artysta uzależniony od środowiska piszący ${ }^{\circ}$ h jakby o społeczeństwie i i jakby na jego użytek.

Czasami mimo różnych zabiegów językowych i parajęzykowych, które ujawniają się na powierzchni m.in. stosowaniem wyrazu jakby, wypowiedź nie jest kontynu- 
owana i ulega urwaniu. W badanym materiale pojawiają się urwania z leksykalną modyfikacją wątku. Tego typu urwanie polega na tym, że „mówca nagle urywa swą wypowiedź, ponieważ ma trudność z wyjaśnieniem zagadnienia. Po urwaniu próbuje jeszcze raz przekazać tę samą treść. Często stosuje przy tym inne słowa, czemu w konsekwencji może towarzyszyć zastosowanie innych struktur gramatycznych" (Majewska-Tworek 2014: 121). Mówca kontynuuje plan swojej wypowiedzi, jednak decyduje się w inny sposób wyjaśnić omawiane zagadnienie.

- tak chodzi mi o to że nie tworzymy yyy wyrazów ${ }^{\circ}$ hyy $(0,3)$ ((cmoka)) jakby (.) / nasz język polega na tym że mamy alfabet i z niego tworzymy tak.

Powyższy przykład ilustruje urwanie, które wystąpiło tuż po zastosowaniu wyrazu jakby. Wahanie mówcy objawia się wykładnikami niepłynności zarówno w jego prawostronnym, jak i lewostronnym otoczeniu.

W zebranym materiale znalazł się też inny od powyżej omówionych typ urwania: urwanie bez nawiązania leksykalnego w prowadzonym wątku. Polega ono na tym, że „mówiący urywa swoją wypowiedź i ponawia eksplikację bieżącego problemu, naświetlając go od innej strony" (ibid.: 123). Mówca we wznowionej wypowiedzi nie wraca już do elementów leksykalno-gramatycznych przerwanej konstrukcji:

- typ $(0,3)$ yyy yyy $(0,2)$ żołnierza ale takiego złego na yyy żołnierza na przykład $(0,5)$ chociaż nie jakby/ bo chciałam tu wspomnieć o działach navarony ale tam w sumie nie ma jednoznacznie negatywnych takich całkiem bohaterów więc tu raczej oh.

Wyraz jakby może być też sygnałem końca jasnego planu wypowiedzi, ponieważ pojawia się w bezpośrednim sąsiedztwie urwań totalnych, czyli takich, które powodują utratę roli mówcy. W badanym materiale widać to w następnym przykładzie. Stosowanie jakby może być sygnałem dla słuchającego, że powinien interweniować. Jest to bardziej prawdopodobne, jeśli wyraz ten pojawia się w otoczeniu innych wykładników niepewności. Warto więc zwrócić uwagę, że studentka na wiele sposobów próbowała odpowiedzieć na postawione pytanie. Powrót do terminu, o który została zapytana, $\mathrm{z}$ zastosowaniem jakby $\mathrm{w}$ prepozycji stał się powodem przerwania jej wypowiedzi przez egzaminatora w zdecydowany sposób?

9 Zamieszczona tabela jest kopią fragmentu transkryptu w programie EXMARaLDA. Pierwsza kolumna zawiera symbole mówców, pierwszy wers - numery segmentów transkryptu oraz - w nawiasach kwadratowych - czas trwania rozmowy w minutach i sekundach, z dokładnością do tysięcznej sekundy. 


\begin{tabular}{|l|l|l|l|l|l|l|}
\hline & $761[13: 06.6]$ & $762[13: 07.1]$ & $763[13: 08.9]$ & $764[13: 09.7]$ & $765[13: 10.7]$ & \\
\hline AW_1483 & $(0.5)$ & $\begin{array}{l}\text { szkieletem } \\
\text { książki nie jest } \\
\text { gramatyka }\end{array}$ & $(0.9)$ & $\begin{array}{l}\text { yyy każdy } \\
\text { temat }\end{array}$ & $(0.4)$ & $\begin{array}{l}\text { jest } \\
\text { tak }\end{array}$ \\
\hline
\end{tabular}

\begin{tabular}{|l|l|l|l|}
\hline &.. & $767[13: 13.2]$ & $768[13: 13.4]$ \\
\hline AD_1489 & & & $\begin{array}{l}\text { ale może pani tak powiedzieć } \\
\text { innymi słowami }\end{array}$ \\
\hline AW_1483 & jakby komunikacyjn yyy & $(0.3)$ & \\
\hline
\end{tabular}

Wyraz jakby może też służyć wygaszaniu mówienia. W badanym materiale znalazł się jeden przykład tego typu. Wydaje się, że w analizowanym jakby jest zawarty swego rodzaju unik przed powtarzaniem wszystkiego, co już w rozmowie zostało powiedziane i ustalone. Właściwa interpretacja sensu jakby polega więc wyłącznie na wiedzy wspólnej nadawcy i odbiorcy wynikającej z przebiegu całego dialogu. Ponadto prowadzący rozmowę egzaminacyjną sam decyduje o stopniu swojej aktywności werbalnej. Decyduje także o momencie jej całkowitego zakończenia.

- mowa pozornie zależna jest tym środkiem $(0,5)$ stylistycznym który pozwala $(0,3)$ osiągnąć (jakby) $(1,1)$

- no dobrze dziękuję bardzo.

Ostatnim typem kontekstu, w którym występuje partykuła jakby, jest kontekst retardacyjny. Wyróżnia się on występowaniem w bezpośrednim kontekście jakby wykładników niepłynności. Nagromadzenie wykładników w poszczególnych kontekstach różni się od siebie stopniem nasilenia. Może to być wyłącznie pauza właściwa lub wypełniona. Często jednak obserwuje się bardzo mocne nagromadzenie wyróżników niepłynności różnego typu. Cechą wyróżniającą jest też to, że mówcy udaje się kontynuować wypowiedź, tzn. nie urywa jej ani nie traci roli nadawcy w dialogu. Ponadto znaczącym wyróżnikiem tego typu fragmentów wypowiedzi jest liczna, choć nieobligatoryjna, obecność autokorekt różnego typu:

- oh yyy dobrze a ja chciałam zapytać no bo to jest to co jest jakby w u w po w podstawach a co się yyy stało we współczesnej co się dzieje we współczesnej literaturze;

- oh anomalia ${ }^{\circ} \mathrm{h}$ yyy to występowanie yyy odstępstw od reguł $(0,3)^{\circ} \mathrm{h}$ yyy $(0,3)$ chodzi o to yyy jakby ta s yyy spór zaczął się od $(0,7)$ yyy ((mlaszcze)) (.) ten ta problematyka od starożytności. 
W takich kontekstach następuje znaczące osłabienie znaczenia leksykalnego jakby lub jego całkowita deleksykalizacja.

W zebranym materiale znalazły się tylko dwa przykłady wyrazu jakby występującego w funkcji spójnika. Pochodzą od tego samego mówcy. Mają charakter spójnika centralnego, który - jak podaje ISJP - wprowadza zdanie podrzędne określające sytuację, która nie musi być rzeczywista (por. też powyżej - podrozdział o częściach mowy):

- yyy tut tak zabrzmiało jakby tutaj pisarz powieści politycznej kierował się resentymentem;

- no tak to pani sformułowała jakby to było $(0,3)$ prawie identyczne.

W zbiorze przykładów pochodzących z rozmów oficjalnych nie znalazły się wyrazy jakby w funkcji spójnika podrzędnego warunkowego. Może to wynikać ze specyfiki gatunkowej tekstów, z których pochodzi badany materiał. Wypowiedzi ocenianych studentów koncentrują się na referowaniu wiedzy, a nie budowaniu hipotez, które staraliby się w swych wypowiedziach udowadniać czy chociażby rozważać.

\section{Wnioski}

Zbierająca wyniki szczegółowych analiz tabela wyraźnie pokazuje zróżnicowanie obecności leksemów o postaci jakby w dwóch badanych gatunkach mowy. Rozmowę nieoficjalną charakteryzuje częstsze wykorzystywanie partykuł hipotetycznych oraz użycie spójnika centralnego i warunkowego. Natomiast w oficjalnej rozmowie egzaminacyjnej odmiennej pod względem intencji, sytuacji nadawczo-odbiorczych, stylu oraz zakresów tematycznych spotykamy partykuły asekuracyjne, uspójniające i retardacyjne. Wystąpienia spójnikowe są jednostkowe.

Tabela 1. Części mowy a wyrazy o postaci jakby w rozmowach nieoficjalnych i oficjalnych

\begin{tabular}{llcc} 
& Części mowy & Rozmowa nieoficjalna & Rozmowa oficjalna \\
\hline \multirow{3}{*}{ Partykuła } & asekuracyjna & $12 \%$ & $15 \%$ \\
& hipotetyczna & $24 \%$ & - \\
\multirow{2}{*}{ Partykuła } & uspójniająca & $21 \%$ & $25 \%$ \\
& retardacyjna & $9 \%$ & $58 \%$ \\
\multirow{2}{*}{ Spójnik } & centralny & $8 \%$ & $2 \%$ \\
& warunkowy & $26 \%$ & -
\end{tabular}




\section{Literatura}

Danielewiczowa M., 2006, Do czego służy słowo „raczej”?, „Polonica” XXVI/XXVII, s. $83-100$.

DoboszyńsKa-MARKIEWICZ K., 2015, O „jakby nieostrości” i jej „swego rodzaju” operatorach (linguistic hedges) - uwagi wstępne, „Linguistica Copernicana” 12, s. 137-155, [on-line:] https://doi.org/10.12775/LinCop.2015.006.

GeWiss: Gesprochene Wissenschaftssprache kontrastive, [on-line:] gewiss.uni-leipzig.de.

Grochowski M., 1984, Program metodologiczny opisu partykut, „Sborník prací Filozofické fakulty Brněnské univerzity. Studia Minora Facultatis Philosophicae Universitatis Brunensis" A 32, s. 77-88.

GrZEGORCZY KOWA R., 1996, Wykłady z polskiej składni, Warszawa.

ISJP: M. Bańko (red.), Inny słownik języka polskiego, t. I-II, Warszawa 2000.

Majewska-Tworek A., 2014, Niepłynność wypowiedzi w oficjalnej odmianie polszczyzny. Propozycja typologii, Wrocław.

Majewska-Tworek A., ZAśKo-Zielińska M., 2016, Funkcje wyrazu „no” w nieoficjalnych i oficjalnych wypowiedziach mówionych na tle opisu leksykograficznego, [w:] M. Zaśko-Zielińska, M. Misiak, J. Kamieniecki, T. Piekot (red.), Lingua et gaudium. Księga jubileuszowa ofiarowana profesorowi Janowi Miodkowi, Wrocław, s. 447-463.

Majewska-Tworek A., ZaśKo-Zielińska M., 2018, Funkcje leksemów o postaci „właśnie” w nieoficjalnych i oficjalnych wypowiedziach mówionych na tle opisu leksykograficznego, [w:] A. Piotrowicz, M. Witaszek-Samborska, K. Skibski (red.), Kultura komunikacji potocznej w językach słowiańskich, „Kultura Komunikacji Językowej”, t. 5, Poznań, S. 203-219.

MilczanowsKa-MatejCzy A A., 2009, Wypowiedź zdeterminowana i umotywowana: użycia wyrażeń „jakby” i „jak gdyby” we współczesnej polszczyźnie mówionej, [w:] B. Dunaj, M. Rak (red.), Polszczyzna mówiona ogólna i regionalna. Materiały ogólnopolskiej konferencji naukowej, Kraków, 25-26 września 2008 r., „Biblioteka LingVariów”, t. 5, Kraków, s. $327-335$.

Narodowy Korpus Języka Polskiego, praca zbiorowa, red. A. Przepiórkowski, M. Bańko, R.L. Górski, B. Lewandowska-Tomaszczyk, Warszawa 2012.

NKJP: Narodowy Korpus Języka Polskiego, [on-line:] nkjp.pl.

PęDZIK P., 2015, Spokes - a Search and Exploration Service for Conversational Corpus Data, [w:] Selected Papers from the CLARIN 2014 Conference, October 24-25, 2014, Soesterberg, The Netherlands, Linköping, s. 99-109.

PSWP: H. Zgółkowa (red.), Praktyczny słownik współczesnej polszczyzny, t. 1-50, Poznań 1994-2005.

SGJP: Z. Saloni, M. Woliński, R. Wołosz, W. Gruszczyński, D. Skowrońska, Słownik gramatyczny języka polskiego, [on-line:] www.sgjp.pl.

SGPP: M. Grochowski, A. Kisiel, M. Żabowska, Słownik gniazdowy partykuł polskich, Kraków 2014.

SWJP: B. Dunaj (red.), Słownik współczesnego języka polskiego, Kraków 1996.

USJP: S. Dubisz (red.), Uniwersalny słownik języka polskiego, t. I-IV, Warszawa 2003.

WAjszczuk J., 1997, System znaczeń w obszarze spójników polskich. Wprowadzenie do opisu, Warszawa. 
Wajszczuk J., 2011, Co właściwie spójniki łączą? Powrót do pytań zasadniczych, „Prace Filologiczne” LX, s. 263-286.

WDK SPOKEs: Wyszukiwarka Danych Konwersacyjnych, [on-line:] spokes.clarin-pl.eu.

Wielki słownik języka polskiego PAN. Geneza, koncepcja, zasady opracowania, praca zbiorowa, red. P. Żmigrodzki, M. Bańko, B. Batko-Tokarz, J. Bobrowski, A. Czelakowska, M. Grochowski, R. Przybylska, J. Waniakowa, K. Węgrzynek, Kraków 2018.

WSJP PAN: P. Żmigrodzki (red.), Wielki słownik języka polskiego PAN, [on-line:] wsjp.pl.

ŻABowsкA M., 2006, Zróżnicowanie semantyczne partykuł epistemicznych, "LingVaria” nr 1 (1), s. 203-213.

ŻAвоwsка M., 2007, Jednostki komunikujace wybór odpowiedniego wyrażenia, „Prace Filologiczne" LII, s. 451-46o.

Żydek-BednARCZUK U., 2005, Wprowadzenie do lingwistycznej analizy tekstu, Kraków.

\section{Functions of Words of the jakby-type in Unofficial and Official Spoken Utterances. Based on Corpus Analysis \\ Summary}

The goal of the paper is to describe the function of words of the jakby-type in unofficial and official utterances, compared to their lexicographic descriptions. The analysis has been based on transcripts of oral examination interviews, and unofficial conversations. It revealed the differences in the functional load of words of the jakby-type in these two types of conversations. 